\title{
Influence of Raw Meat Content on 3D-Printing and Rheological Properties
}

\author{
Marius Herold ${ }^{a^{*}}$, Sören Morick ${ }^{\mathrm{b}}$, Oliver Hensel ${ }^{\mathrm{c}}$, And Uwe Grupa ${ }^{\mathrm{b}}$ \\ ${ }^{\mathrm{a}}$ University of Applied Science Fulda, Regional Innovation Centre for Health and Quality of Life Fulda \\ (RIGL), Leipzigerstrasse 123, D 36037 Fulda, Germany \\ ${ }^{\mathrm{b}}$ University of Applied Science Fulda, Department of Food Technology, Leipzigerstrasse 123, D 36037 Fulda, \\ Germany \\ ${ }^{c}$ Faculty of Organic Agricultural Sciences, Section of Agricultural Engineering, University of Kassel, \\ Nordbahnhofstrasse 1 a, 37213, Witzenhausen, Germany \\ * Corresponding author \\ marius.herold@lt.hs-fulda.de \\ TEL.: +496619640 - 1975
}

Received: 10 December 2019; Published online: 18 April 2021

Invited paper from the e-conference on Food Texture and Rheology

\begin{abstract}
The aim of this study was to investigate the influence of raw chicken meat content on the rheological properties and $3 \mathrm{D}$ printability of minced meat mixtures using different concentrations of raw and cooked chicken meat. The meat mass contained yolk, crushed ice, lean raw meat and cooked meat with a high concentration of connective tissue. The concentrations of raw meat added to cooked meat as a percentage of the total weight of meat were $0 ; 30 ; 40 ; 50 ; 60 ; 70$ and 100 . To determine the rheological properties, amplitude sweep and frequency sweep were carried out with a Rheostress RS 300 (Thermo Fisher Scientific Inc.). Cubes were printed, and the printability and optical impression were evaluated using grades from 1-5. The results showed that rheological properties had a strong influence on the printability of meat mass and it is necessary for G' (storage modulus) at the LVR (linear viscoelastic region) to be higher than $7000 \mathrm{~Pa}$. The complex viscosity $\left|\eta^{*}\right|$ should be higher than $170 \mathrm{~Pa}$, at a shear stress $\tau=10 \mathrm{~Pa}$, and a frequency $\mathrm{f}=10 \mathrm{~Hz}$ used to guarantee sufficient solidity.
\end{abstract}

Keywords: 3D-printing; Rheological properties; Amplitude sweep; Viscosity

\section{Introduction}

3D-printing belongs to additive manufacturing processes. Material is added layer by layer, with a predefined thickness, to create complex freeform structures (Godoi, Prakash \& Bhandari, 2016). The advantage of this technology is that it is possible to produce customized products. Nowadays, it is possible to print different materials like plastics, building material, ceramics, metal and food by a 3D-printer (Fastermann, 2012). Personalised nutrition is getting more and more important (Daniel, Klein \& analysiert die Varianz, 2016). By producing food with a 3Dprinter it is possible to find solutions to meet the individual needs of each customer. Therefore, it is possible to customise the content of vitamins, minerals, protein and fat in the food. In order to print food, the food must be available as a homogenous mass. The rheological properties of this mass define the printability (Liu, Zhang, Bhandari \& Yang, 2018). By adding connective tissue to a printable mass, the rheological properties will change. So it is necessary to 
check rheological properties such as storage modulus ( $G^{\prime}$ ) and loss modulus (G") before printing starts. Liu, Zhang et al. (2018) printed mashed potatoes with various contents of starch. They found that added starch influences the rheological properties and also the printability (Liu, Zhang et al., 2018). Also the flow behaviour is an important factor in 3D-printing (Wang \& Shaw, 2005). If one conveys product through a nozzle the shear rate will increase as the pipe diameter decreases. The viscosity will also increase if the fluid is dilatant. This makes it difficult to print dilatant products such as those with a high content of starch. The influence of rheological properties on 3D-printing has been extensively studied (Avery et al., 2014; Shao, Chaussy, Grosseau \& Beneventi, 2015; Zhang et al., 2015). However, the literature and current knowledge about the influence of rheological properties on the printability of food masses are very scarce. The aim of this research was to investigate the influence of raw meat content on the rheological properties and the printability of minced meat. Minced meat represents a food with a high content of protein.

\section{Materials and Methods}

\subsection{Preparation of the meat mass}

To produce minced meat from chicken, deepfrozen chicken carcasses (Buckl Geflügel Ltd.) were thawed at $5{ }^{\circ} \mathrm{C}$ for 3 days in cold storage. While dissecting the chicken carcasses, the meat was grouped in two categories: the first category was lean meat with a low content of connective tissue (inside and outside filet, m. supracoracoideus and $\mathrm{m}$. pectoralis) and the second category was meat with a high content of connective tissue. The meat with a high content of connective tissue came from the legs (m. iliotibialis, m. iliofibularis, m. fibularis, m. flexor perforans \& perforatus), spine (m. latissimus dorsi, $\mathrm{m}$. intercostales, $\mathrm{m}$. serratus superficialis) and also skin and tendon. The lean meat was cut out of the chicken. The rest of the chicken was cooked in a boiler (WarmMaster E, Merten \& Storck Ltd.) at $90{ }^{\circ} \mathrm{C}$ for 3 hours in a bag (PA/PE composite film) so as to break down the connective tissue by thermal energy. After cooking, the rest of the meat was deboned and minced by a moulinette (Moulinex Typ 6430, SEB Germany Ltd). The meat juice, formed during the thermal processing and caught in the bag, was also added to the cooked meat. After preparation, the meat was stored for 12 hours at 5 ${ }^{\circ} \mathrm{C}$ until it was processed. To produce the meat mass, the lean meat and the cooked meat with a high content of connective tissue were mixed in a meat processor (UMC5, Stephan Food Service Equipment $\mathrm{GmbH}$ ) by adding crushed ice, yolk and sunflower oil (see Table 1). Crushed ice was added to cool down the mass while grinding. Preliminary investigation showed that yolk and sunflower oil improved the printability (data not presented). Only the two types of meat were added in various ratios (see Table 1). While grinding the meat, the wall of the Stephan UMC 5 was cooled by cold water to keep the temperature of the meat mass below $8{ }^{\circ} \mathrm{C}$ during processing. Hereafter, for better understanding, the concentration of cooked meat and raw meat as a percentage is related to the total weight of meat.

\subsection{D-Printing \& rheological properties}

The thick paste extruder (see Figure 1), with a nozzle diameter of $2 \mathrm{~mm}$, was used with the 3D-Printer ZMorph 2.0S (ZMorph Ltd.). The printer was controlled by "Voxalizer 64bit" software. To evaluate the printability, five cubes were printed out for each batch. The temperature of the meat was measured with a digital thermometer (GTH 175/MO, Greisinger Electronic Ltd.) before and after the printing process. The average meat temperature was $20{ }^{\circ} \mathrm{C}$. The cube form was defined by a G-Code, a document that defines xyz-coordinates for the extruder, as well as the piston moving speed and extrusion rate. The G-Code was created as part of this work. To build a cube, 6 layers were printed. Each layer had 7 parallel rows. The layers were $90^{\circ}$ rotated to the next layer. Before starting to print, the extruder was filled, air-free, with the meat mass. Then five cubes were printed. While printing the extrusion rate was $0.009 \mathrm{~cm}^{3} \mathrm{~s}^{-1}$, the temperature of the heating bed was $20^{\circ} \mathrm{C}$ and the nozzle 
Table 1: Composition of each batch

\begin{tabular}{|c|c|c|c|c|c|c|c|}
\hline sunflower oil $[\mathrm{g}]$ & \multicolumn{7}{|c|}{10} \\
\hline yolk $[\mathrm{g}]$ & \multicolumn{7}{|c|}{10} \\
\hline crushed ice $[\mathrm{g}]$ & \multicolumn{7}{|c|}{100} \\
\hline cooked meat with a high concentration of connective tissue $[\mathrm{g}]$ & 0 & 150 & 200 & 250 & 300 & 350 & 500 \\
\hline raw lean meat $[\mathrm{g}]$ & 500 & 350 & 300 & 250 & 200 & 150 & 0 \\
\hline concentration of raw meat in total meat [\%] & 100 & 70 & 60 & 50 & 40 & 30 & 0 \\
\hline
\end{tabular}

moving speed was $2 \mathrm{cms}^{-1}$. The cubes and printing process were rated with grades from 1 to 5 . The best grade was 1 and 5 was the worst. The printability and the optical impression were used for the evaluation, which included consideration of contour definition, stability and layout of the lines. While printing the rheological properties of the meat mass were checked. All the rheological tests were done in triplicate. Amplitude sweep and frequency sweep were performed with the Rheostress RS 300 (Thermo Fisher Scientific Inc.) using a $60 \mathrm{~mm}$ parallel plate with a gap of 2 $\mathrm{mm}$. First the LVR was determined by an amplitude sweep. The measurements by a frequency test have to be within the limits of the LVR. The amplitude sweep was carried out by controlled shear stress (CS mode) of $\tau=1$ Pa to $\tau=1000$ $\mathrm{Pa}$ in 20 steps (logarithmic distribution) at a constant frequency of $\mathrm{f}=1 \mathrm{~Hz}$ to determine the course of G' and the complex viscosity $\left|\eta^{*}\right|$. The complex viscosity stands for the flow resistance of the sample. It approximates to the dynamic viscosity because the measurement was taken at the LVR (Meichsner, Mezger \& Schröder, 2003). To specify the frequency range, samples were measured between 0.1 to $100 \mathrm{~Hz}$ in 20 steps (logarithmic distribution) at a constant shear stress of $\tau=10 \mathrm{~Pa}$.

\section{$3 \quad$ Results and Discussion}

\subsection{Amplitude Sweep}

The amplitude sweep shows that the yield point $\tau_{y}$ increased with an increase of raw meat content. The content of raw meat between 30 and $60 \%$ showed nearly identical yield points at the same level (see Figure 2). Outside of this range the yield point was reached earlier. The yield point correlated with the content of raw meat $(\alpha=0.05)$ for a quadratic relationship. A high content of raw meat results in a high content of non-cross-linked proteins. Non cross linked proteins were able to interconnect and act in this case as an emulsifier to absorb water (Sielaff, 1996). If the sample was able to interconnect, it had a reversible behavior at higher shear rate. That caused a higher yield point and also a larger LVR. If the shear rate was above $\tau_{y}$ the LVR was left and the deformation started to be irreversible. This area is also called the "yield zone" (Mezger, 2016). At the LVR-Plateau, the elastic modulus ( $\left.G^{\prime}\right)$ increased with an increase of raw meat content (see Figure 3$)(\alpha=0.05)$. The higher the concentration of raw meat the higher the elastic modulus $\left(\mathrm{G}^{\prime}\right)$. A high $\mathrm{G}^{\prime}$ indicated a high degree of interconnectedness and a higher content of bound water in the meat. Only non coagulated proteins were able to interconnect and to emulsify water (Sielaff, 1996). The content of non-coagulated proteins was higher in raw meat. When proteins were able to connect they form a network. This generated network increased the ability to absorb mechanical stress, and therefore G' was higher. In meat with a high content of connective tissue, all proteins were denatured and not able to connect to each other.

\subsection{Frequency Sweep}

The results of the Frequency Sweep also showed that G' depends on the content of raw meat. It was difficult to distinguish the course of G' because the gradient of each curve was different 


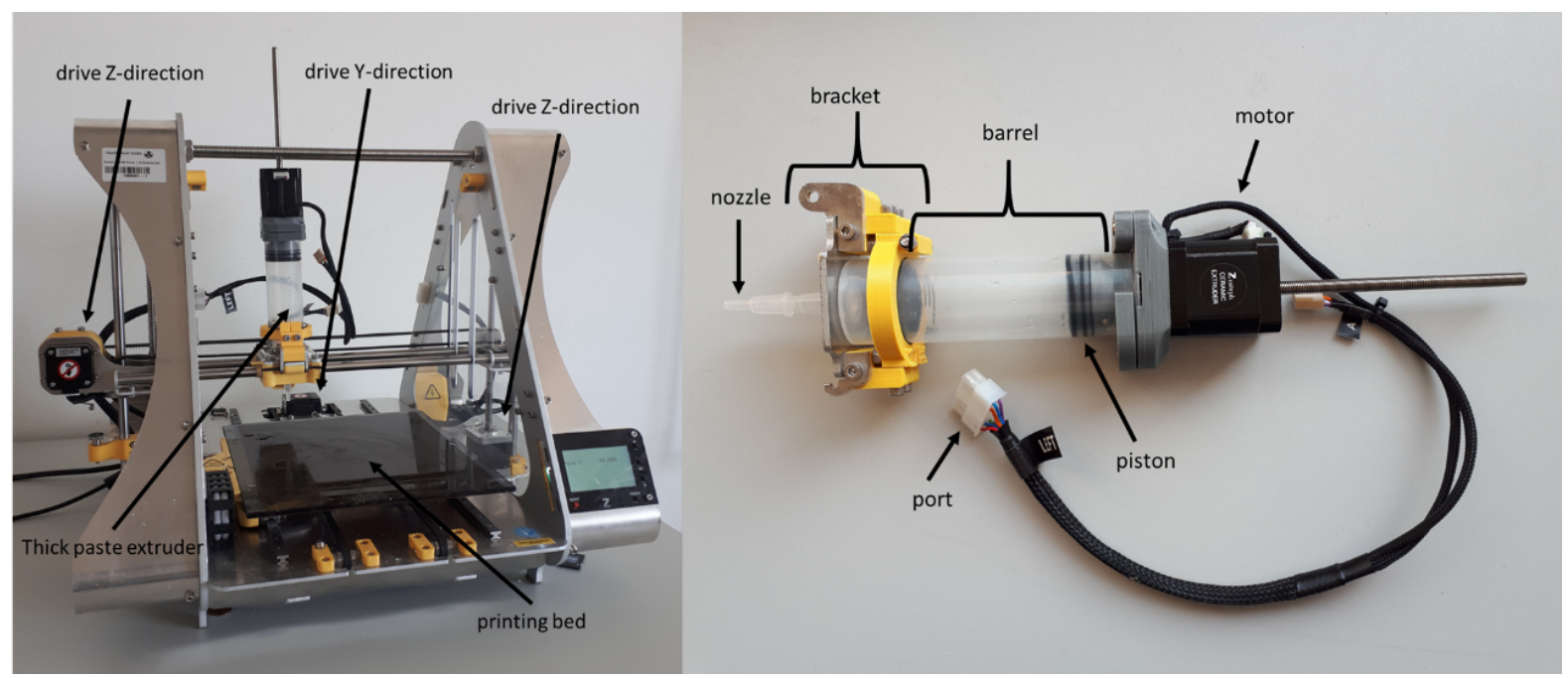

Figure 1: Zmorph 3D-Printer (left), with all the components, and thick paste extruder (right)

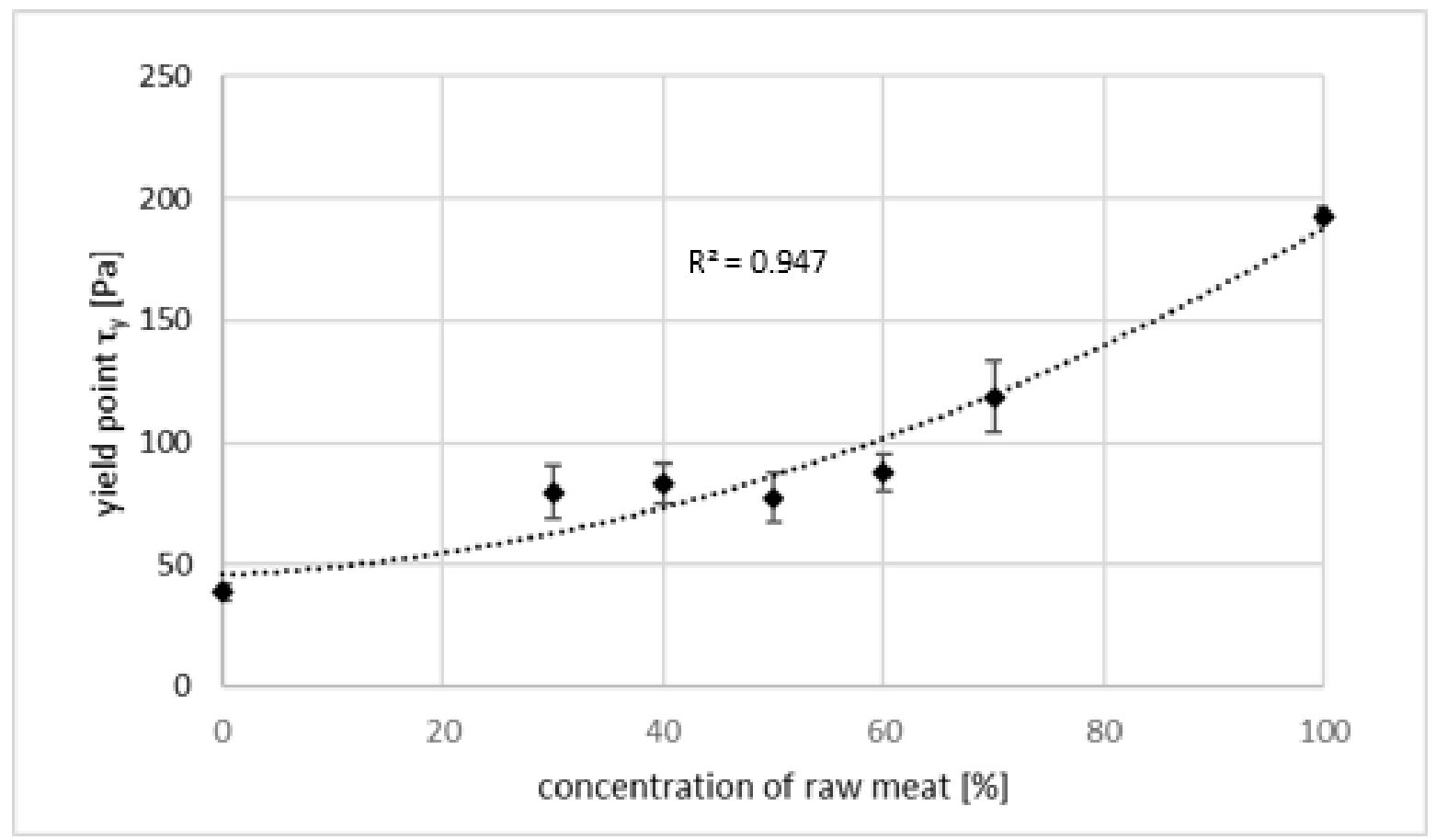

Figure 2: Yield point dependence on the concentration of raw meat, with error bars for the standard error of the mean (triple determination) 
3D-printing of meat | 199

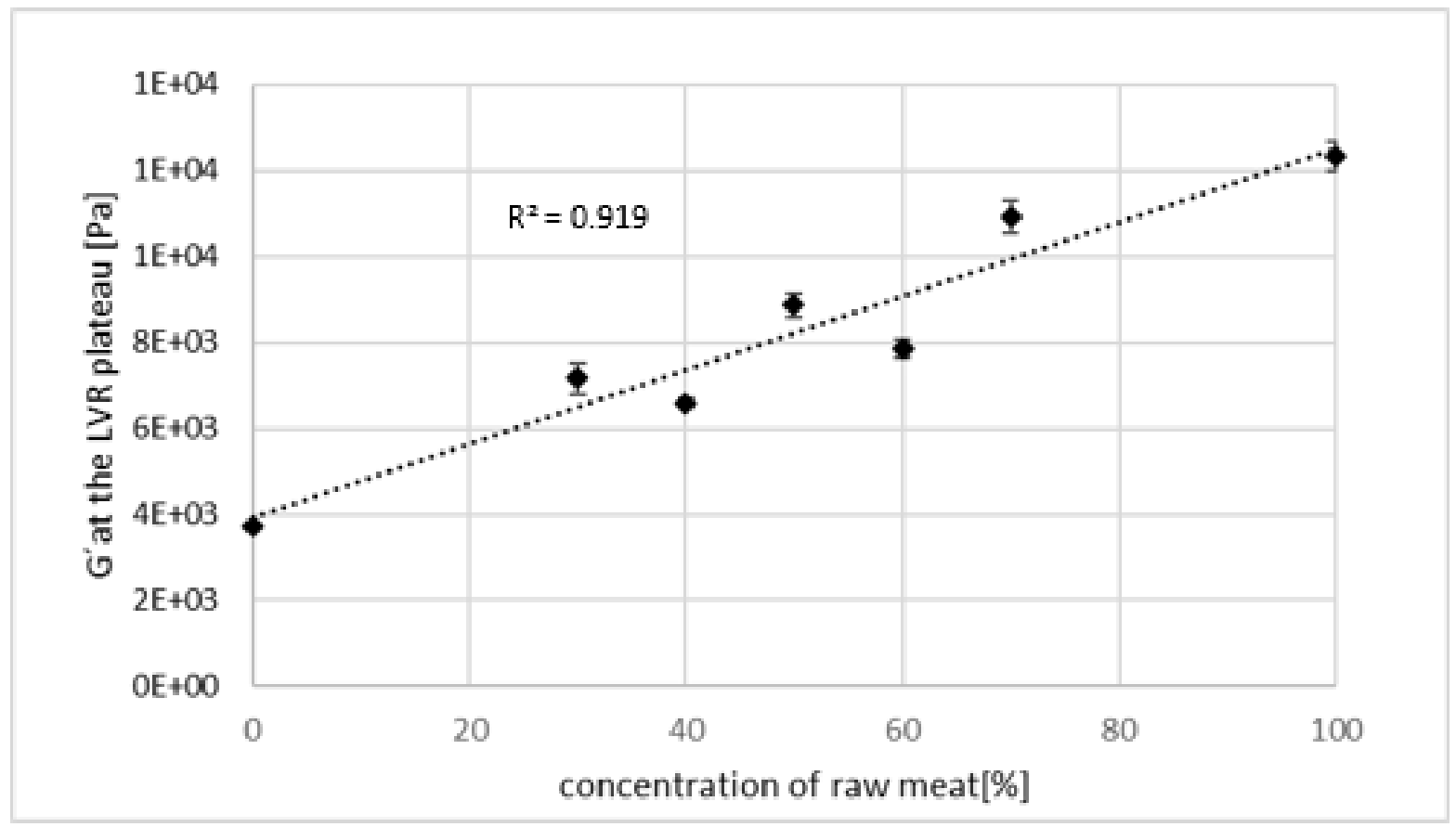

Figure 3: G' at the LVE plateau dependence on the content of raw meat, with error bars for the standard error of the mean (triple determination)

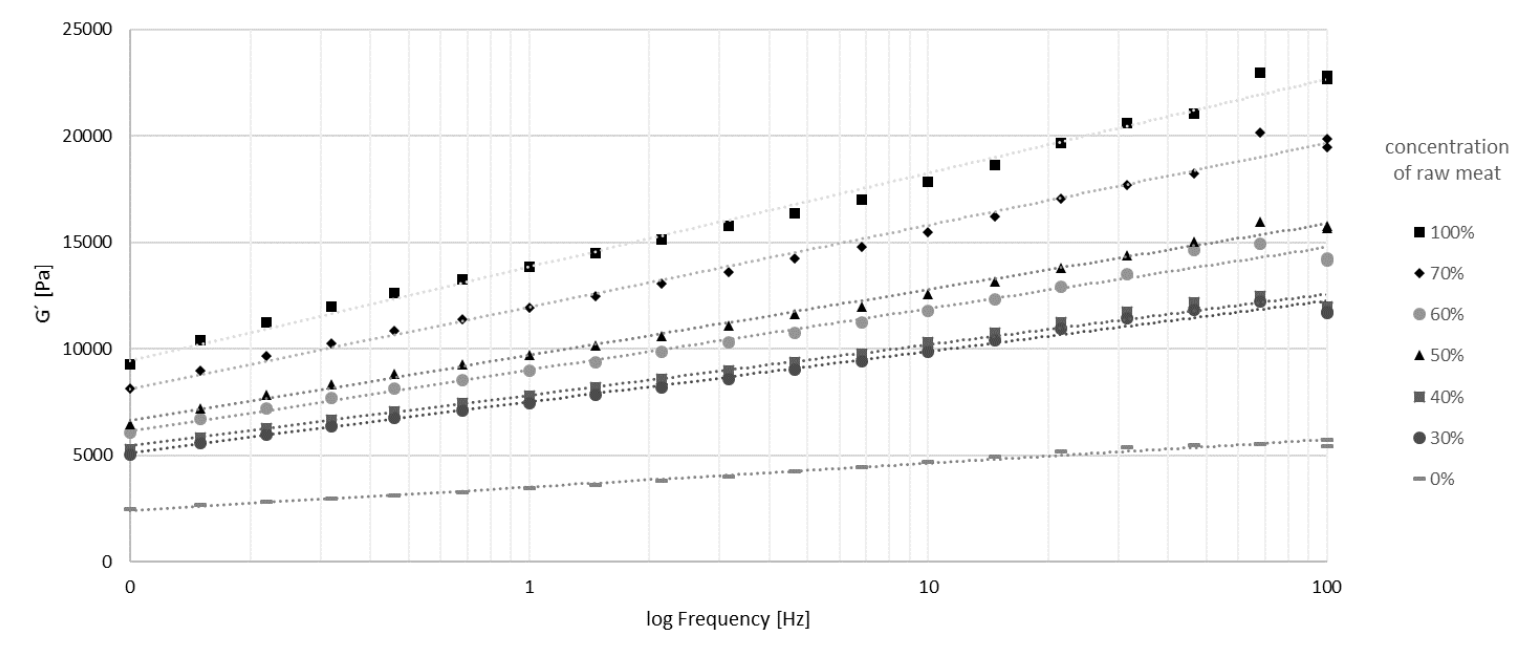

Figure 4: G' dependence on frequency at various contents of raw meat 


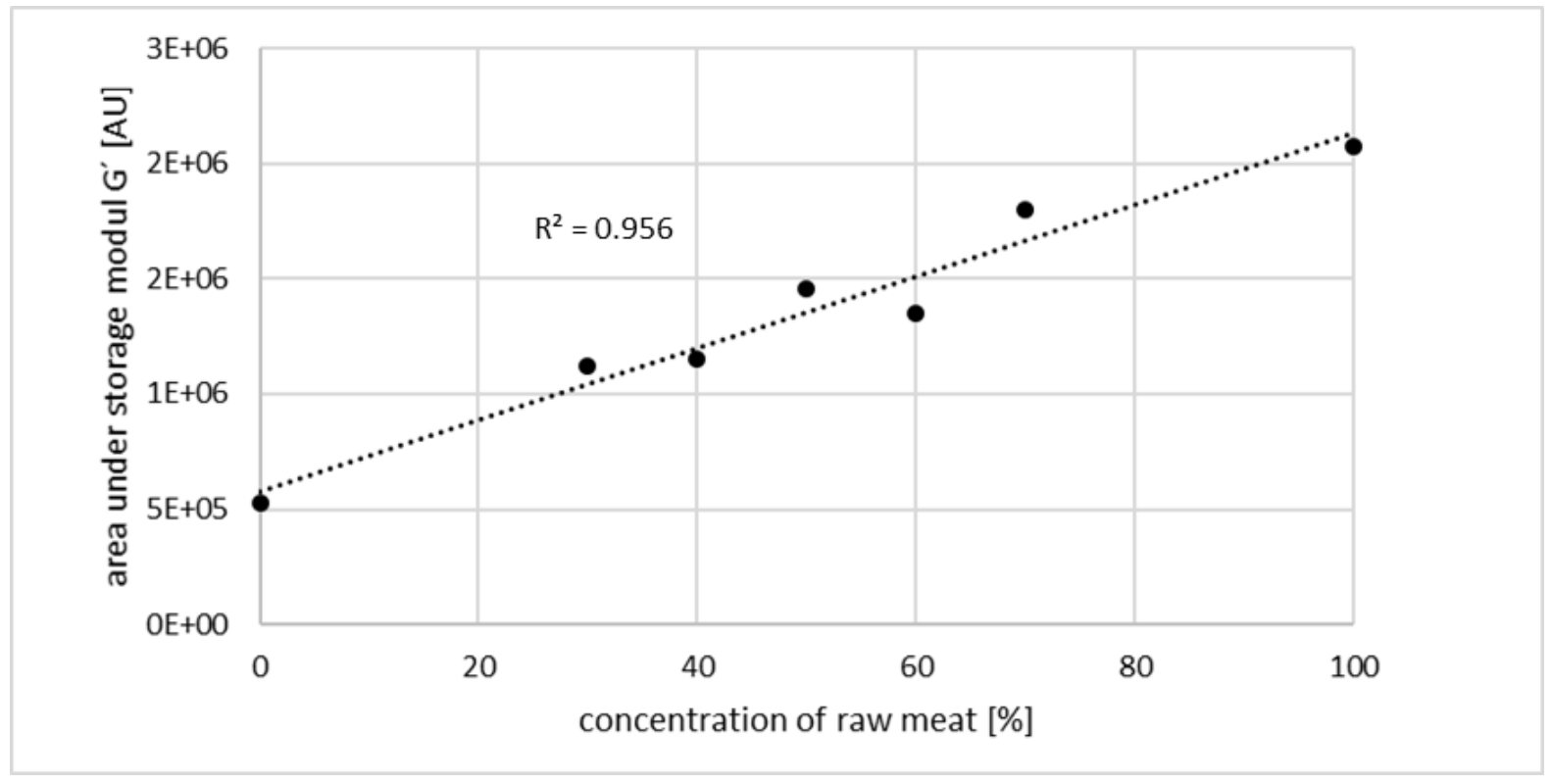

Figure 5: Area under storage modul dependence on the content of raw meat

\begin{tabular}{|c|c|c|c|c|c|c|c|}
\hline $\begin{array}{c}\text { concentration of } \\
\text { raw meat }\end{array}$ & $0 \%$ & $30 \%$ & $40 \%$ & $50 \%$ & $60 \%$ & $70 \%$ & $100 \%$ \\
\hline $\begin{array}{c}\text { marks for } \\
\text { printability }\end{array}$ & 4.5 & 3 & 2 & 1.5 & 1 & 1.5 & 1 \\
\hline $\begin{array}{c}\text { marks for optical } \\
\text { impression }\end{array}$ & 4.5 & 3 & 2 & 1.5 & 1 & 1.5 & 1 \\
\hline
\end{tabular}

Figure 6: Pictures of printed cubes with corresponding marks for printability and optical impression at different concentrations of raw meat 


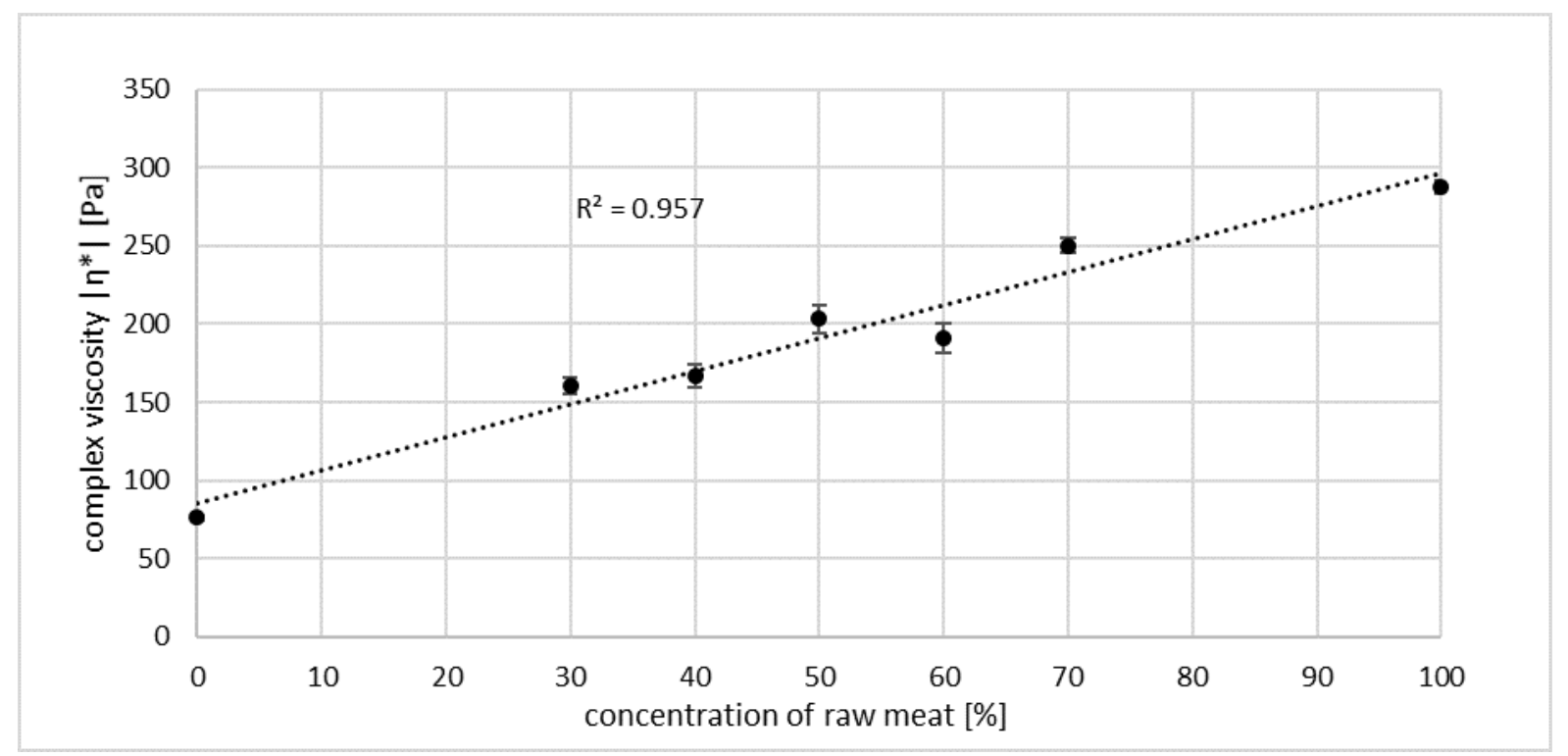

Figure 7: Complex viscosity dependence on the content of raw meat, measured at shear stress $\tau=10$ $\mathrm{Pa}$ and frequency $\mathrm{f}=10 \mathrm{~Hz}$, with error bars for the standard error of the mean

(Figure 4). The method of choice was to integrate each line and correlate the area with the concentration of raw meat. It correlates with $\mathrm{R}^{2}=0.956(\alpha=0.05) \quad$ (Figure 5). The area under $G$ ' increased with a higher content of raw meat. High G' also stood for a higher degree of intermolecular connections. Proteins were able to build connections to each other through hydrogen bonds, Van-der-Waals-forces and hydrophobic effects. After heating the proteins this ability was lost as they would move freely (Ebermann \& Elmadfa, 2008).

\section{$3.3 \quad 3 \mathrm{D}$-printing}

Printability and optical impression were improved with a higher content of raw meat. The achieved results were acceptable at $>50 \%$ of raw meat. The higher the content of raw meat, the finer the printed lines and the more delicate the appearance. Also the surface was smoother at higher raw meat content. More research is needed to understand the relationship between raw meat content and the optical impression of the surface. A low content of raw meat $(0 \%$ -
$30 \%$ ) induced an unstable form, where the cubes became wider at the base (see Figure 6). The fibres in the denatured meat gave the product an irregular surface. Generally, it can be said that with higher G' printability and optical impression are improved because of the higher content of non-cross-linked proteins in the raw meat (Rezler, Piotrowska, Dolata \& Wojciechowski, 2007). The cubes with a content of raw meat above $50 \%$ were able to build a protein network. The meat would rest for 12 hours after production so that the proteins had enough time to build intermolecular connections. These connections increased the stability and also the storage modulus G'. Figure 7 shows the course of the complex viscosity $\left|\eta^{*}\right|$ dependence on the content of raw meat. The higher the content of raw meat the higher the viscosity $(\alpha=0.05)$. A high viscosity caused a high stability because the printing mass was prevented from flowing away during and after the printing process (Liu, Ho \& Wang, 2018). The desired shape could be printed and kept. 


\section{Conclusion}

This investigation shows that the rheological properties had a significant influence on printability and stability of printed products. The G' at the LVR-Plateau should be higher than 7000 Pa. The complex viscosity $\left|\eta^{*}\right|$ should be higher than $170 \mathrm{~Pa}$ at a shear stress $\tau=10 \mathrm{~Pa}$ and frequency $\mathrm{f}=10 \mathrm{~Hz}$ to ensure sufficient firmness. The printability increased with the content of raw meat. The content of non-denatured proteins is sufficient to enable dimensionally stable printed cubes at a raw meat content above $50 \%$.

\section{Acknowledgements}

We acknowledge support by the Open Access Publishing Fund of Hochschule Fulda - University of Applied Sciences.

\section{References}

Avery, M. P., Klein, S., Richardson, R., Bartlett, P., Adams, G., Dickin, F. \& Simske, S. (2014). The rheology of dense colloidal pastes used in 3d-printing. In Nip \& $d i$ gital fabrication conference (Vol. 2014, 1, pp. 140-145). Society for Imaging Science and Technology.

Daniel, H., Klein, U. \& analysiert die Varianz, D. N. (2016). Personalisierte ernährung. J. Für Ernährungsmedizin, 13, 6-9.

Ebermann, R. \& Elmadfa, I. (2008). Lehrbuch lebensmittelchemie und ernährung. Springer-Verlag.

Fastermann, P. (2012). 3d-druck/rapid prototyping: Eine zukunftstechnologie-kompakt erklärt. Springer-Verlag.

Godoi, F. C., Prakash, S. \& Bhandari, B. R. (2016). 3d printing technologies applied for food design: Status and prospects. Journal of Food Engineering, 179, 44-54. doi:10 . 1016/j.jfoodeng.2016.01.025

Liu, C., Ho, C. \& Wang, J. (2018). The development of $3 \mathrm{D}$ food printer for printing fibrous meat materials. In 2nd International Conference on Innovative Engineering Materials (ICIEM 2017) (Vol. 284). IOP Conference Series-Materials Science and Engin- eering. 2nd International Conference on Innovative Engineering Materials (ICIEM), Philadelphia, PA, OCT 21-23, 2017. doi:10. 1088/1757-899X/284/1/012019

Liu, Z., Zhang, M., Bhandari, B. \& Yang, C. (2018). Impact of rheological properties of mashed potatoes on $3 \mathrm{~d}$ printing. Journal of Food Engineering, 220, 76-82. doi:10.1016/ j.jfoodeng.2017.04.017

Meichsner, G., Mezger, T. \& Schröder, J. (2003). Lackeigenschaften messen und steuern. Vincentz Network GmbH \& Co KG.

Mezger, T. G. (2016). Das Rheologie Handbuch: 5. Farbe Und Lack.

Rezler, R., Piotrowska, E., Dolata, W. \& Wojciechowski, M. (2007). Effect of the substitution of meat by a protein preparation on the rheological properties of finely-comminuted sausage forcemeats. Acta Agrophysica, 9(1), 221-231.

Shao, Y., Chaussy, D., Grosseau, P. \& Beneventi, D. (2015). Use of microfibrillated cellulose/lignosulfonate blends as carbon precursors: Impact of hydrogel rheology on 3d printing. Industrial \& Engineering Chemistry Research, 54(43), 10575-10582. doi:10.1021/acs.iecr.5b02763

Sielaff, H. (1996). Fleischtechnologie. Mitteilungen Aus Dem Gebiete Der Lebensmitteluntersuchung Und Hygiene, 87, 368-369.

Wang, J. W. \& Shaw, L. L. (2005). Rheological and extrusion behavior of dental porcelain slurries for rapid prototyping applications. Materials Science and Engineering A-structural Materials Properties Microstructure and Processing, 397(1-2), 314321. doi:10.1016/j.msea.2005.02.045

Zhang, M., Vora, A., Han, W., Wojtecki, R. J., Maune, H., Le, A. B. A., ... Nelson, A. (2015). Dual-responsive hydrogels for direct-write 3d printing. Macromolecules, 48(18), 6482-6488. doi:10 . 1021 / acs . macromol.5b01550 